UDK $577.1: 61$

ISSN 1452-8258

J Med Biochem 37: 364-372, 2018

Original paper

Originalni naučni rad

\title{
HIGH-SENSITIVITY TROPONINS AFTER A STANDARDIZED 2-HOUR TREADMILL RUN
}

\author{
VISOKOOSETLIVI TROPONINI POSLE STANDARDIZOVANOG \\ DVOČASOVNOG TRČANJA NA POKRETNOJ TRACI
}

\author{
Pavel Broz 1,4, Daniel Rajdl1,4, Jaroslav Novak², Milan Hromadka3, \\ Jaroslav Racek ${ }^{1,4}$, Ladislav Trefil ${ }^{1}$, Vaclav Zeman ${ }^{2}$ \\ ${ }^{1}$ Institute of Clinical Biochemistry and Haematology, University Hospital in Pilsen, Pilsen, Czech Republic \\ ${ }^{2}$ Department of Sports Medicine, Charles University in Prague, Prague, Czech Republic \\ ${ }^{3}$ Department of Cardiology, University Hospital in Pilsen, Pilsen, Czech Republic \\ ${ }^{4}$ Faculty of Medicine in Pilsen, Charles University in Prague, Prague, Czech Republic
}

\section{Summary}

Background: The aim of this study was to examine highsensitivity troponin T and I (hsTnT and hsTnl) after a treadmill run under laboratory conditions and to find a possible connection with echocardiographic, laboratory and other assessed parameters.

Methods: Nineteen trained men underwent a standardized 2-hour-long treadmill run. Concentrations of hsTnT and hsTnl were assessed before the run, 60, 120 and 180 minutes after the start and 24 hours after the run. Changes in troponins were tested using non-parametric analysis of variance (ANOVA). The multiple linear regression model was used to find the explanatory variables for hsTnT and hsTnl changes. Values of troponins were evaluated using the $\mathrm{Oh} / \mathrm{h}$ algorithm.

Results: Changes in hsTnT and hsTnl levels were statistically significant $(p<0.0001$ and $p<0.0001$, respectively). In a multiple regression model (adjusted $R^{2}: 0.60, p=0.005$ for hsTnT and adjusted $\mathrm{R}^{2}$ : 0.60, $p=0.005$ for hsTnl), changes in both troponins can be explained by relative left wall thickness (LV), training volume, body temperature after the run and creatinine changes. According to the $\mathrm{Oh} / \mathrm{1h}$ algorithm, none of the runners was evaluated as negative.

Conclusions: Relative LV wall thickness, creatinine changes, training volume and body temperature after the run can

Address for correspondence:

Pavel Broz

Institute of Clinical Biochemistry and Haematology, Charles University and University Hospital in Pilsen, Alej Svobody 80, 304 60, Czech Republic e-mail: brozp@fnplzen.cz

\section{Kratak sadržaj}

Uvod: Cilj ove studije bio je da se ispitaju nivoi visokoosetljivih troponina T i I (hsTnT i hsTnl) posle trčanja na pokretnoj traci u laboratorijskim uslovima i da se utvrdi potencijalna povezanost sa ehokardiografskim, laboratorijskim i ostalim procenjivanim parametrima.

Metode: Devetnaestorica muškaraca podvrgnuti su standardizovanom dvočasovnom trčanju na pokretnoj traci. Koncentracije hsTnT i hsTnl određene su pre trčanja, zatim 60, 120 i 180 minuta posle početka i 24 časa posle završetka trčanja. Promene u troponinima testirane su pomoću testa ANOVA. Model višestruke linearne regresije upotrebljen je za pronalaženje eksplanatornih varijabli za promene u hsTnT i hsTnl. Vrednosti troponina određene su pomoću algoritma Oh/1h. Rezultati: Promene u nivoima hsTnT i hsTnl bile su statistički značajne $(p<0,0001$ i $p<0,0001)$. U modelu višestruke regresije (prilagođeni $\mathrm{R}^{2}$ : 0,60, $\mathrm{p}=0,005$ za hsTnT i prilagođeni $R^{2}: 0,60, p=0,005$ za hsTnl), promene oba troponina mogu se objasniti promenama u relativnoj debljini levog zida (LV), obimu prethodnih treninga, temperaturi tela posle trčanja i kreatininu. Prema algoritmu $\mathrm{Oh} / 1 \mathrm{~h}$, nijedan od trkača nije ocenjen kao negativan.

Zaključak: Relativna debljina zida LV, promene u nivou kreatinina, obim prethodnih treninga i temperatura tela posle trčanja mogu predvideti promene u nivoima hsTnT i hsTnl.

List of abbreviations: ANOVA, analysis of variance; BMI, body mass index; BSA, body surface area; CKD-EPI, chronic kidney disease epidemiology collaboration; cTn, cardiac troponins; GFR, glomerular filtration rate; $H R$, heart rate; $\mathrm{H}$ max, maximum heart rate; hsTnl, high-sensitivity troponin I; hsTnT, highsensitivity troponin $\mathrm{T}$; LiHep, lithium heparine; K3EDTA, Kalium Ethylene-Diamine-Tetra-Acetic acid; LV, left ventricle; $\mathrm{NGAL}$, neutrophil gelatinase-associated lipocalin; $U$, urine; $\mathrm{VC}$, vital capacity; $\mathrm{VCO}_{2}$, carbon dioxide expenditure; $\mathrm{VO}_{2}$, oxygen uptake; $\mathrm{VO}_{2}$ max, maximum oxygen uptake. 
predict changes in hsTnT and hsTnl levels. When medical attention is needed after physical exercise, hsTn levels should be tested only when clinical suspicion and the patient's history indicate a high probability of myocardial damage.

Keywords: high-sensitivity troponins, running, standardized exercise, echocardiography

\section{Introduction}

High-sensitivity cardiac troponin (hsTn) examination is a modern assessment method widely used in the diagnosis of myocardial damage (1). In comparison with conventional troponin assays, hsTn assays can detect minimal amounts of released cardiac troponins (cTn), even in healthy individuals (2). Physical exercise is a useful tool in the prevention of many medical conditions, e.g. cardiovascular diseases and osteoporosis (3). Many people worldwide spend hours weekly engaging in physical activity at the professional or nonprofessional level; however, hospitalization after strenuous exercise from cardiac or noncardiac causes, even in young athletes without previous symptoms, can occur (4).

Despite many publications on the subject, the pathophysiological mechanism of cTn release after physical exercise and its consequences is not fully understood; however, possible explanations have been published (5). Studies focused on hsTn changes during controlled laboratory-based exercise are rare $(6,7)$. Hospitalization after strenuous exercise (e.g. after completing a half-marathon) is not uncommon, and clinical symptoms suspicious of cardiac aetiology can be present.

Our first goal was to find the possible connection between hsTn changes and echocardiographic, renal and anthropometric parameters examined before and during the standardized 2-hour treadmill run. Minor goal was to evaluate high-sensitivity troponin I (hsTnl) and high-sensitivity troponin T (hsTnT) using the European Society of Cardiology 2015 0/1 rapid rule-out and rule-in algorithm for the diagnosis of non-ST-elevation myocardial infarction (8).

\section{Material and Methods}

\section{Subjects}

Nineteen men were enrolled in the study. The inclusion criteria were history of successfully finishing a marathon under 3 hours and 30 minutes in the past year; non-smokers and no history of cardiovascular and renal disease, diabetes mellitus, neoplasia or chronic medication. The anthropometric parameters and training histories of all runners are summarized in Table $I$.
Kada je posle fizičkog vežbanja potrebna medicinska asistencija, nivoe hsTn trebalo bi testirati samo ukoliko klinička sumnja i istorija bolesti ukazuju na veliku verovatnoću oštećenja miokarda.

Ključne reči: visokoosetljivi troponini, trčanje, standardizovana vežba, ehokardiografija

Table I Anthropometric parameters and training histories of runners enrolled in the study $(n=19)$.

\begin{tabular}{|l|c|}
\hline Age (years) & $37(24-48)$ \\
\hline $\mathrm{BMI}\left(\mathrm{kg} \times \mathrm{m}^{-2}\right)$ & $22.8(20.6-27.2)$ \\
\hline $\begin{array}{l}\text { Running-training volume } \\
(\mathrm{km} \text { per month) }\end{array}$ & $160(100-350)$ \\
\hline Physical activity (hours per week) & $14(10-22)$ \\
\hline $\mathrm{VO}_{2} \mathrm{max}\left(\mathrm{mL} \times \mathrm{kg}^{-1} \times \mathrm{min}^{-1}\right)$ & $59.7(36.9-75.3)$ \\
\hline $\mathrm{HR}$ (resting) (beats per minute) & $51(40-65)$ \\
\hline $\mathrm{VC}(\mathrm{mL})$ & $5370(4560-6950)$ \\
\hline
\end{tabular}

Data are presented as median (min-max). BMI - body mass index, $\mathrm{VO}_{2}$ max - maximum oxygen uptake, $\mathrm{HR}$ - heart rate, VC - vital capacity.

\section{Study design}

All participants received a questionnaire regarding their medical condition and training history prior to the study. Before the main experiment, all participants underwent two visits. The first visit was to perform a resting echocardiographic and blood pressure examination. The second visit was to perform a resting 12-lead electrocardiogram to find possible pathologies and to reveal ECG signs of hypertrophy using the Cornell voltage criteria followed by a graded treadmill run test to determine the aerobic capacity of each participant (9). The main experiment including the 2-hour treadmill run was performed during the third visit, at which time five blood samples were drawn. The last blood sample was obtained during the fourth visit ( 24 hours after the treadmill run). The study design is illustrated in Figure 1. No physical activity was allowed for one day before the third visit and for 24 hours after. Intensive or strenuous activity (e.g. competition) was not allowed during the last 14 days before the main experiment. All participants gave written informed consent, and the study was approved by the local ethics committee.

\section{Echocardiographic examination}

All participants underwent an initial echocardiographic examination to exclude possible abnormali- 


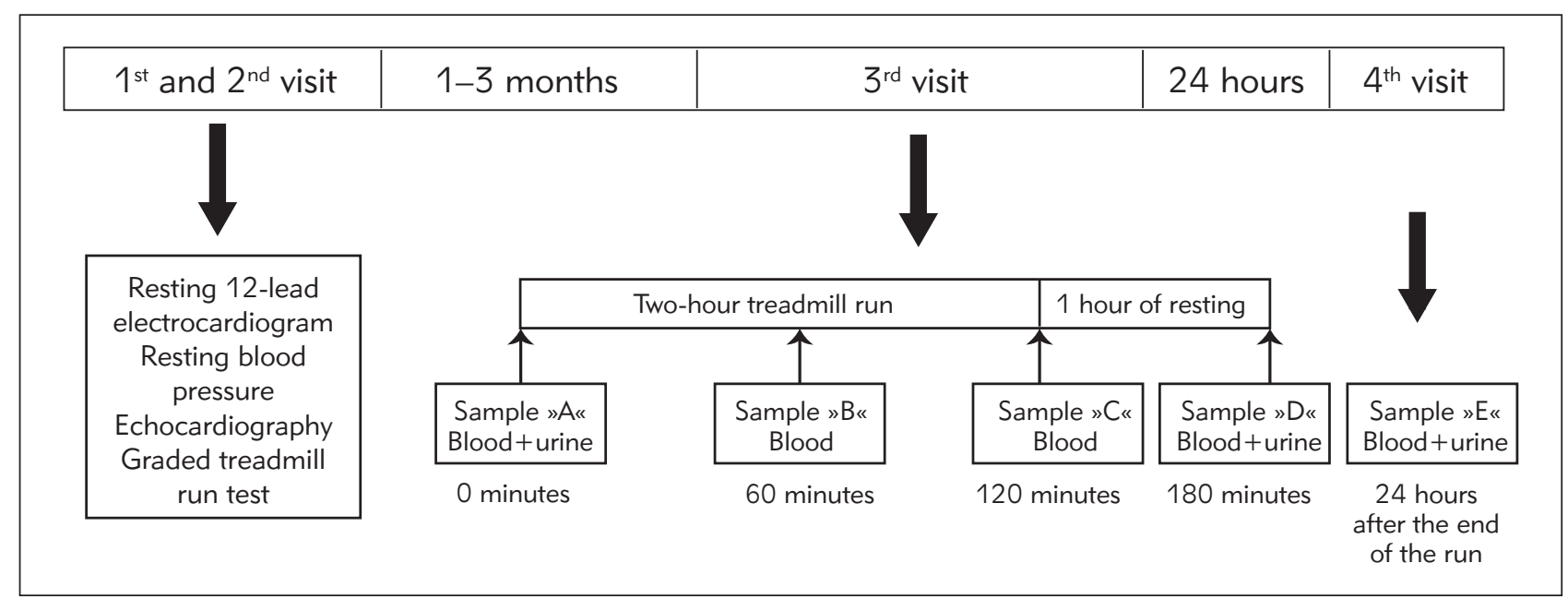

Figure 1 Study design.

ties and to determine left ventricle (LV) mass values, LV wall thickness and LV diastolic diameter. Before the echocardiographic examination, blood pressure was measured on the left arm while the participant was in a sitting position after 5 minutes of rest (Omron M6 Comfort, Omron Healthcare Co, Kyoto, Japan). Two-dimensional, M-mode and Doppler echocardiograms were acquired using an ultrasound system (Vivid 7, GE Medical Systems, Horton, Norway) with a 3.4-MHz multi-frequency transducer. Primary measurements of mitral inflow included the peak early filling (E-wave) and late diastolic filling (A-wave) velocities, the E/A ratio and deceleration time of the early filling velocity, which were derived by placing the cursor of the pulsed wave Doppler in the LV, above the tips of the mitral valve, to display the onset of mitral inflow, using a $5 \mathrm{MHz}$ transducer. Passive LV filling ( $E^{\prime}$-wave) was measured from the pulsed wave tissue Doppler of the mitral septal annular velocity. Right ventricular systolic pressure was based on the measurement of maximal tricuspid regurgitation velocity and applying the modified Bernoulli equation before addition of the estimated right atrial pressure. LV mass values were calculated according to the Cube formula (10). One experienced cardiologist performed all echocardiographic examinations.

\section{Graded treadmill run}

For maximum oxygen uptake $\left(\mathrm{VO}_{2} \mathrm{max}\right)$, maximum heart rate (HR max), ventilation and anaerobic threshold determination, a progressive exercise test on a treadmill ergometer (LODE, Groningen, the Netherlands) was used. The workload started at a running velocity of $7 \mathrm{~km} \times \mathrm{h}^{-1}$ for 3 minutes, then was increased to $9 \mathrm{~km} \times \mathrm{h}^{-1}$ for the next 3 minutes, and the runners covered the last 3-minute sub-maximal workload at a running velocity of $11 \mathrm{~km}^{-1}$. Following a 9-minute warm-up, the running velocity was increased by $1 \mathrm{~km} \times \mathrm{h}^{-1}$ every $30 \mathrm{~s}$ to the point of exhaustion. During the entire test, the $\mathrm{O}_{2}$ and $\mathrm{CO}_{2}$ concentrations in the exhaled air were analysed by an $\mathrm{O}_{2}-\mathrm{CO}_{2}$ Junkalor analyser (Saxon Junkalor, Dessau, Germany) with Pewatron gas sensors (Pewatron, Zürich, Switzerland). Heart rate was monitored by a Polar heart rate meter (Polar, Kempele, Finland). All data were automatically computerized in 30-s intervals: heart rate $(\mathrm{HR})$, oxygen uptake $\left(\mathrm{VO}_{2}\right)$, carbon dioxide expenditure $\left(\mathrm{VCO}_{2}\right)$, pulmonary ventilation, respiratory rate, respiratory exchange ratio and ventilatory equivalent for $\mathrm{O}_{2}$ and $\mathrm{CO}_{2}$.

\section{Two-hour treadmill run}

After a 10-minute warm-up run at $8 \mathrm{~km} \times \mathrm{h}^{-1}$, the speed was increased gradually until the target velocity was reached. The target speed was set at $90 \%$ of the heart rate at the anaerobic threshold. Participants were allowed to drink ad libitum during the entire run. Every 15 minutes, all participants were asked about their subjective feelings of perceived exertion, and the results were noted using the Borg scale (11). Ventilatory parameters $\left(\mathrm{VO}_{2}, \mathrm{VCO}_{2}\right)$ and $\mathrm{HR}$ were monitored throughout the entire run. When any of the parameters monitored started to indicate that the anaerobic threshold was exceeded, the speed was reduced by $1 \mathrm{~km} \times \mathrm{h}^{-1}$. One 5 -minute-long pause was necessary to allow blood sampling after 1 hour. The body temperature was measured rectally immediately after the run.

\section{Blood samples and biochemistry assessment}

All blood samples were taken from the antecubital vein while the participant was in a sitting position. Blood samples were taken before the run - sample "A«, 1 hour after the start - sample »B«, at the end of the run ( 2 hours after the start) - sample "C", 1 hour after the end of the run ( 3 hours after the start) - sample »D« and 24 hours after the end of the 
run - sample »E«(Figure 1). In sample "A», three blood samples were taken - 1x VACUETTE ${ }^{\circledR}$ TUBE 4 $\mathrm{ml}$ Kalium Ethylene-Diamine-Tetra-Acetic acid (K3EDTA) and 2x VACUETTE® TUBE $4 \mathrm{~mL}$ Lithium heparine (LiHep) Separator, Greiner Bio-One $\mathrm{GmbH}$, Kremsmünster, Austria. At all other time points, 2 blood LiHep samples were taken. Urine samples were taken at the same time as samples »A«, "D $\mathrm{D}$ and » $\mathrm{E}$ " (1x VACUETTE ${ }^{\circledR}$ Urine tube). All LiHep samples were centrifuged 15 minutes after collection at 2000 $\mathrm{g}$ for 10 minutes. Samples were stored at $-70{ }^{\circ} \mathrm{C}$ prior to analysis.

\section{Sample analysis}

In all runners, routine analysis of the K3EDTA sample "A" was performed (erythrocytes, leukocytes, platelet count, haemoglobin, bilirubin, aspartate aminotransferase, alanine aminotransferase, creatinine, urea, total protein). Erythrocyte, leukocyte, platelet count and haemoglobin concentration were performed on an automated haematological analyser (Beckman Coulter, DxH 800 Beckman Coulter, Krefeld, Germany). Bilirubin, aspartate aminotransferase, alanine aminotransferase, creatinine, urea, cystatin C, total protein, albumin, lactate and hsTnT analysis were performed using the Cobas system (Cobas 8000 Analyzer, Cobas c702 and e602 modules, Roche Diagnostics, Basel, Switzerland). Urine albumin concentrations were assessed using the Cobas system (Cobas 6000, Cobas c501, Roche Diagnostics, Basel, Switzerland). HsTnl analysis was performed using the Abbott system (STAT High Sensitive Troponin-I, Abbott Architect i2000SR, Abbott Diagnostics, Düsseldorf, Germany). NGAL was determined by using a Beckman Coulter analyser (Beckman Coulter AU 640, Beckman Coulter, Lismeehan, O'Callaghan's Mills, Co. Clare, Ireland, NGAL Test BioPorto, BioPorto Diagnostics A/S, Hellerup, Denmark). All samples were analysed in batches. The limit of detection was $2 \mathrm{ng} \times \mathrm{L}^{-1}$ for hsTnl and $5 \mathrm{ng} \times \mathrm{L}^{-1}$ for hsTnT.

\section{Statistical analysis}

Unless stated otherwise, descriptive statistics are expressed as median (min-max) values. Because of the relatively small sample size and non-normally distributed data, non-parametric tests were used. Trends in hsTnT and hsTnl levels were tested by using the non-parametric alternative to the one-way analysis of variance (ANOVA) for repeated measures (Friedman test). Relative changes in hsTnT and hsTnl (difference between peak value and sample "A« value) were used for comparisons between parameters. To calculate the number of samples that fell below and above the 99th percentile in males only and in the whole population, concentrations of 15.5 and $14.0 \mathrm{ng} \times \mathrm{L}^{-1}$, respectively, were used for hsTnT, whereas 27.0 and $19.3 \mathrm{ng} \times \mathrm{L}^{-1}$, respectively, were used in the case of
hsTnl $(12,13)$. The Spearman correlation coefficient was used to compare changes in hsTnT and hsTnl, and for echocardiographic, anthropometric, biochemical and other parameters assessed before and during the 2-hour treadmill run. The level of statistical significance was set at $\alpha=0.05$. The multiple linear regression model was employed with the relative changes in hsTnT and hsTnl as the dependent (explained) variables. The relevant explanatory (independent) variables were selected by a stepwise (backward and forward, $p$ for inclusion < 0.1) algorithm from the following parameters: age; BMI; body temperature after the run; relative LV wall thickness; relative LV diastolic diameter; median of lactate; physical activity performed weekly and relative changes in creatinine, cystatin, myoglobin, NGAL/creatinine and albumin/creatinine urine ratios. For statistical analysis, MedCalc software (MedCalc Software, version 16.4.1, MedCalc Software bvba, Ostend, Belgium) and $\mathrm{R}$ software (version 3.1.3, R Development Core Team, R Foundation for Statistical Computing, Vienna, Austria) were used. Samples " $\mathrm{C}$ " and "D» were stratified according to the $\mathrm{Oh} / \mathrm{h}$ algorithm into "positive«, »negative« or "observe« groups (sample "C» at the end of the run represented »hour 0 « and sample »D« represented »hour $1 \ll$ ).

\section{Results}

ECG and echocardiographic examination showed no significant pathologic findings using previously defined criteria $(10,14)$. Echocardiographic parameters and data from the 2-hour run are stated in Table II.

Table II Echocardiographic parameters and values measured throughout the whole 2-hour-long treadmill run.

\begin{tabular}{|c|c|}
\hline LV mass $(\mathrm{g})$ & $169.0(125.0-247.0)$ \\
\hline LV mass/BSA $\left(\mathrm{g} \times \mathrm{m}^{-2}\right)$ & $85.1(66.2-119.3)$ \\
\hline LV wall thickness (rel) & $0.36(0.27-0.47)$ \\
\hline LV diastolic diameter $\left(\mathrm{mm}^{2}\right)$ & $50.0(46.0-60.0)$ \\
\hline LV diastolic diameter $\left(\mathrm{mm} \times \mathrm{m}^{-2}\right)$ & $26.0(21.4-28.7)$ \\
\hline HR (beats per minute) & $160.0(126.0-180.0)$ \\
\hline Distance $(\mathrm{km})$ & $25.0(18.0-28.0)$ \\
\hline Liquids intake (L) & $0.5(0.1-1.65)$ \\
\hline Body temperature after run $\left({ }^{\circ} \mathrm{C}\right)$ & $39.5(38.4-40.6)$ \\
\hline Borg scale & $13.0(10.5-14.8)$ \\
\hline Weight difference $(\mathrm{kg})^{*}$ & $-2.4(-0.3--5.0)$ \\
\hline $\mathrm{VO}_{2} / \mathrm{VO}_{2} \max (\%)$ & $39.5(38.4-40.6)$ \\
\hline
\end{tabular}

LV - left ventricle, BSA - body surface area. Values stated as median (min-max), HR - heart rate, $\mathrm{VO}_{2}$ - oxygen uptake, $\mathrm{VO}_{2}$ max - maximum oxygen uptake. ${ }^{*}$ Weight difference calculated as difference between weight before and after the 2-hour treadmill run. 
Table III *Number of cases (\%) in particular samples where hsTnl and hsTnT concentrations reached values above the $99^{\text {th }}$ percentile. As the cut-off values for the $99^{\text {th }}$ percentile for males only and the whole population, values of 15.5 and $14 \mathrm{ng} \times \mathrm{L}^{-1}$, respectively, were used for hsTnT, whereas 27 and $19.3 \mathrm{ng} \times \mathrm{L}^{-1}$, respectively, were used in the case of hsTnl $(12,13)$.

\begin{tabular}{|c|c|c|c|c|c|}
\hline & Sample A & Sample B & Sample C & Sample D & Sample E \\
\hline hsTnT* & $2(11 \%) / 2(11 \%)$ & $2(11 \%) / 2(11 \%)$ & $9(47 \%) / 11(58 \%)$ & $12(63 \%) / 13(68 \%)$ & $3(16 \%) / 3(16 \%)$ \\
\hline $\begin{array}{l}\text { Median } 1^{\text {st }}-3^{\text {rd }} \\
\text { quartile (min-max) } \\
(\mathrm{ng} / \mathrm{L})\end{array}$ & $\begin{array}{c}7.2 \\
5.6-8.5 \\
(5.0-41.1)\end{array}$ & $\begin{array}{c}10.6 \\
7.6-12.5 \\
(6.0-64.1)\end{array}$ & $\begin{array}{c}14.8 \\
11.4-20.3 \\
(7.7-65.1)\end{array}$ & $\begin{array}{c}18.5 \\
12.0-22.0 \\
(6.4-61.0)\end{array}$ & $\begin{array}{c}8.7 \\
7.4-11.8 \\
(5.0-41.2)\end{array}$ \\
\hline $\begin{array}{l}\text { Between sample } \\
\text { difference (hsTnT) }\end{array}$ & - & $\begin{array}{c}\text { A-B } \\
p<0.0001\end{array}$ & $\begin{array}{c}\mathrm{A}-\mathrm{C} \\
\mathrm{p}<0.0001\end{array}$ & $\begin{array}{c}\text { A-D } \\
p<0.0001\end{array}$ & $\begin{array}{c}A-E \\
p=0.014\end{array}$ \\
\hline hsTnl* & $0(0 \%) / 0(0 \%)$ & $0(0 \%) / 0(0 \%)$ & $0(0 \%) / 0(0 \%)$ & $1(5.3 \%) / 4(21 \%)$ & $0(0 \%) / 0(0 \%)$ \\
\hline $\begin{array}{l}\text { Median } 1^{\text {st }}-3^{\text {rd }} \\
\text { quartile (min-max) } \\
(\mathrm{ng} / \mathrm{L})\end{array}$ & $\begin{array}{c}3.4 \\
2.3-4.4 \\
(2.0-12.9)\end{array}$ & $\begin{array}{c}3.9 \\
2.2-4.7 \\
(2.0-13.0)\end{array}$ & $\begin{array}{c}5.6 \\
4.5-8.5 \\
(2.5-17.5)\end{array}$ & $\begin{array}{c}8.0 \\
5.8-14.5 \\
(3.4-38.8)\end{array}$ & $\begin{array}{c}4.7 \\
3.9-9.5 \\
(2.0-16.3)\end{array}$ \\
\hline $\begin{array}{l}\text { Between sample } \\
\text { difference (hsTnl) }\end{array}$ & - & $\begin{array}{c}A-B \\
p=0.05\end{array}$ & $\begin{array}{c}\text { A-C } \\
p<0.0001\end{array}$ & $\begin{array}{c}\text { A-D } \\
p<0.0001\end{array}$ & $\begin{array}{c}\text { A-E } \\
p<0.0001\end{array}$ \\
\hline
\end{tabular}

Table IV Spearman correlation coefficients and respective $P$ values for relative changes in TnT. Lactate median value was calculated using measurements of samples A-D. In the case of creatinine, myoglobin, cystatin C and GFR, the change was calculated as the relative difference between the minimum and maximum values.

\begin{tabular}{|c|c|c|}
\hline & hsTnT & hsTnl \\
\hline \multicolumn{3}{|l|}{ Two-hour treadmill run } \\
\hline Body temperature after the run $\left({ }^{\circ} \mathrm{C}\right)$ & $r=0.40 p=0.09$ & $r=0.26 p=0.3$ \\
\hline HR (median) & $r=0.41 p=0.08$ & $r=0.28 p=0.24$ \\
\hline Borg scale (median) & $r=0.10 p=0.68$ & $r=0.09 p=0.73$ \\
\hline $\mathrm{VO}_{2} / \mathrm{VO}_{2}$ max uptake & $r=0.09 p=0.73$ & $r=0.10 p=0.69$ \\
\hline Body temperature after the run & $r=0.40 p=0.09$ & $r=0.26 p=0.30$ \\
\hline Weight difference & $r=0.12 p=0.62$ & $r=-0.19 p=0.45$ \\
\hline Lactate (median)* & $r=0.53 p=0.02$ & $r=0.53 p=0.02$ \\
\hline Creatinine (rel. change) & $r=0.54 p=0.02$ & $r=0.53 p=0.02$ \\
\hline Myoglobin (rel. change) & $r=0.62 p=0.005$ & $r=0.52 p=0.02$ \\
\hline Cystatin C (rel. change) & $r=0.12 p=0.63$ & $r=-0.12 p=0.63$ \\
\hline GFR change (rel. change) & $r=0.54 p=0.02$ & $r=0.57 p=0.01$ \\
\hline Albumin/creatinine (U) (rel. change) & $r=0.44 p=0.07$ & $r=0.48 p=0.047$ \\
\hline NGAL/creatinine (U) (rel. change) & $r=0.55 p=0.02$ & $r=0.63 p=0.006$ \\
\hline \multicolumn{3}{|l|}{ Echocardiographic parameters } \\
\hline LV mass (g) & $r=-0.33 p=0.17$ & $r=-0.20 p=0.41$ \\
\hline LV mass/BSA $\left(\mathrm{g} \cdot \mathrm{m}^{-2}\right)$ & $r=-0.37 p=0.12$ & $r=-0.24 p=0.33$ \\
\hline LV wall thickness (rel) & $r=-0.46 p=0.047$ & $r=-0.51 p=0.02$ \\
\hline LV diastolic diameter $\left(\mathrm{mm}^{2}\right)$ & $r=0.12 p=0.62$ & $r=0.18 p=0.47$ \\
\hline LV diastolic diameter $\left(\mathrm{mm} \cdot \mathrm{m}^{-2}\right)$ & $r=0.37 p=0.12$ & $r=0.42 p=0.07$ \\
\hline
\end{tabular}

NGAL - neutrophil gelatinase-associated lipocalin, GFR - glomerular filtration rate calculated using the CKD-EPI creatinine-cystatin combined equation (15), HR - heart rate, LV - left ventricle, BSA - body surface area, U - urine. 


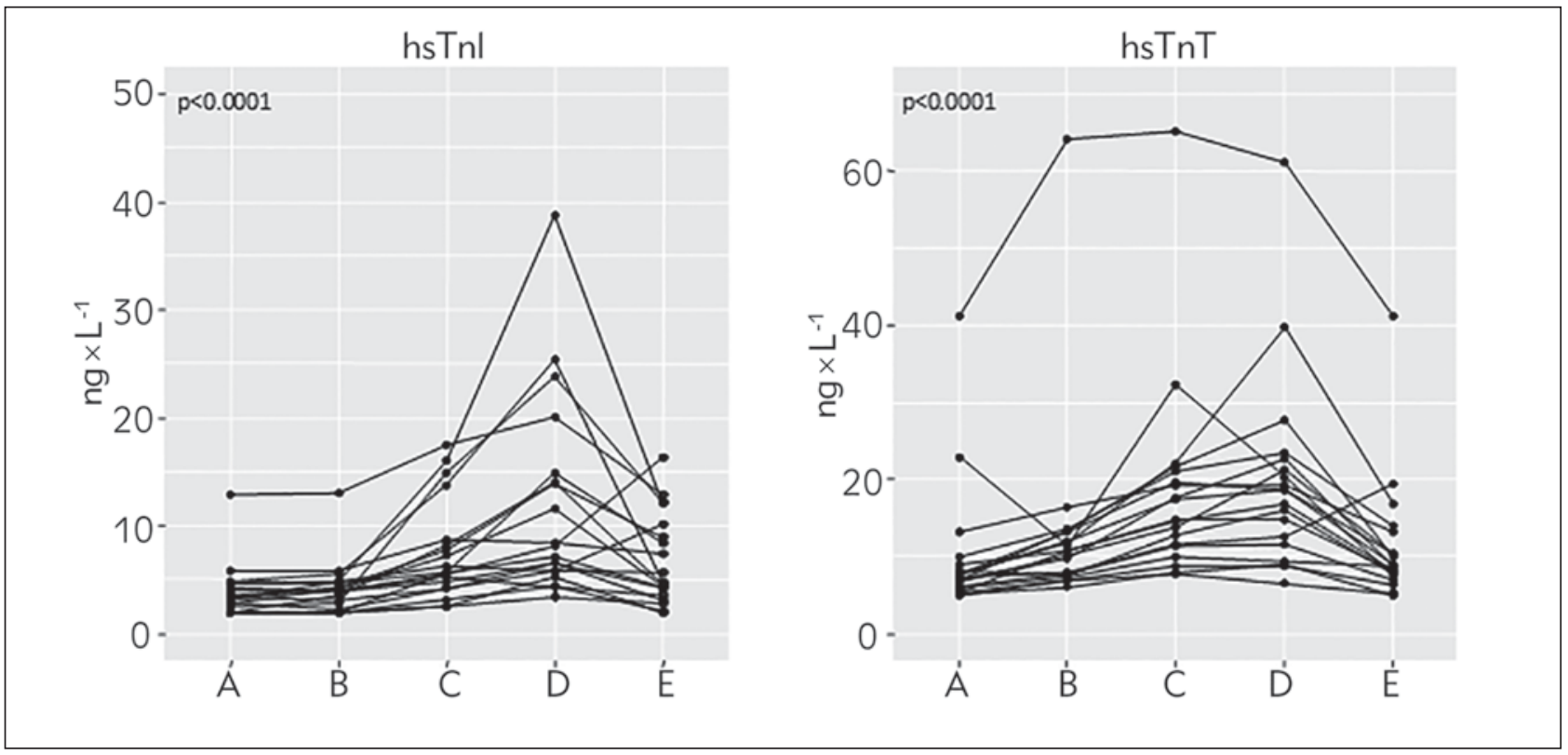

Figure 2 Individual trends in hsTnl and hsTnT concentrations. A - before a 2-hour run, B - 1 hour after the start, C - at the end of the run, $D-1$ hour after the end of the run and $E-24$ hours after the end of the run.

Table V Final multiple linear regression model of relative changes in hsTnT and hsTnl as dependent variables and explanatory variables selected by a stepwise algorithm (for details, see "Statistical analysis« section above). Adjusted $R^{2}: 0.60, p=0.005$ for hsTnT, adjusted R2: 0.60, p = 0.005 for hsTnl.

\begin{tabular}{|l|c|c|c|c|c|c|}
\hline \multirow{2}{*}{} & \multicolumn{3}{|c|}{ hsTnT } & \multicolumn{3}{c|}{ hsTnl } \\
\cline { 2 - 7 } & Estimate & Std. Error & $P$ & Estimate & Std. Error & $P$ \\
\hline Intercept & -5356.94 & 1312.74 & 0.001 & -14738.5 & 3880.48 & 0.003 \\
\hline BMI $\left({\left.\mathrm{kg} \times \mathrm{m}^{-2}\right)}^{*} 20.022\right.$ & 10.922 & 0.09 & 65.692 & 32.285 & 0.06 \\
\hline Body temperature $\left({ }^{\circ} \mathrm{C}\right)$ & 144.378 & 34.654 & 0.001 & 395.559 & 102.439 & 0.002 \\
\hline Physical activity (hours/week) & -14.867 & 5.068 & 0.01 & -47.265 & 14.982 & 0.008 \\
\hline Creatinine (rel. change) & 2.199 & 0.792 & 0.02 & 6.913 & 2.341 & 0.01 \\
\hline $\begin{array}{l}\text { Left ventricle wall } \\
\text { thickness (rel) }\end{array}$ & -1609.30 & 402.89 & 0.002 & -5130.47 & 1190.96 & 0.008 \\
\hline
\end{tabular}

HsTnT and hsTnl levels exhibited statistically significant changes $(p<0.0001$, and $p<0.0001$ resp.). HsTnT and hsTnl changes did not correlate with any of the anthropometric parameters included in Table $I$. Details on correlation analysis of hsTnT and hsTnl with biochemical and echocardiographic parameters and parameters measured throughout the 2-hour treadmill run are summarized in Table $I V$.

According to the multiple linear regression model, the relative change in both troponins can be explained by relative LV wall thickness, time per week spent on physical activity, relative change in creatinine and body temperature after the run measured rectally. Data are summarized in Table V.

One hour after the start, concentrations of hsTnT and hsTnl in sample "B $B$ in comparison with sample "A" were higher in 17 (90\%) and 16 (84\%) cases, respectively. However, the change in hsTnl between samples $A$ and $B$ did not reach statistical significance $(p=0.05)$, in contrast to the change in 
hsTnT $(p<0.0001)$. At the end of the run, concentrations of both troponins in sample $C$ were higher in all runners in comparison with sample »A«. Concentrations of hsTnl and hsTnT declined during the first 24 hours after the end of the run in 17 (90\%) and 18 (95\%) cases, respectively. Individual trends in hsTnT and $\mathrm{hsThl}$ are visualized in Figure 2. The numbers of cases in which hsTnT and hsTnl values reached values above the 99th percentile are summarized in Table III $(12,13)$.

According to the $\mathrm{Oh} / \mathrm{h}$ algorithm for non-ST elevation myocardial infarction diagnosis, in the case of hsTnT, no runner was excluded using the rule-out criteria, $5(26 \%)$ runners were stratified into the "positive " group, and 14 cases were stratified into the "observe" group. In the case of hsTnl, nobody was excluded, 4 (21\%) runners were stratified into the "positive " group and 15 cases were stratified into the "observe« group. Nobody had signs of myocardial infarction during the experiment.

\section{Discussion}

Increased levels of cTn or hsTn after prolonged or strenuous exercise have been widely studied (7, 16-21). The assessment of small changes in troponins is possible by using modern hsTn analytical procedures, whereas the older generations of analytic kits for troponin analysis were not sensitive enough to detect small changes, even after extreme exercise (5, 22). Shave et al. (23) reported an elevation in cTnl in healthy humans after 30 minutes of intensive running. Previous studies were mostly designed to assess cTn or hsTn levels before and after competition (5, 17). As seen in our study, changes in hsTn concentrations can be present even after the first hour of running, and extremely long-duration or high-intensity exercise is not essential.

According to our linear regression model, the most important parameters explaining relative increases in the concentrations of both troponins are increased body temperature after the run, increased creatinine concentration, lower training volume per week and smaller relative LV wall thickness.

Studies assessing hsTn changes and echocardiographic parameters have led to different conclusions $(7,24-26)$. Correlation of changes in cTn levels and cardiac function after exercise is rarely reported (25). We observed that the increase in both troponins can be explained by relative LV wall thickness (the thicker the wall, the smaller the increase in troponins). A thicker $L V$ wall was described as one of the adaptive mechanisms in the hearts of athletes (4). A possible explanation for why a heart with a thicker LV wall releases a smaller quantity of troponins lies in the ability to maintain a higher capacity for mechanical work in comparison with the conceivable worsening of mechanical conditions during contraction of a heart with a thinner wall. Examination of natriuretic peptides would be the appropriate way to address this topic.

As we observed, relative changes in hsTnT and hsTnl can be influenced positively by training volume and negatively by the body temperature measured after the run. Thus, individuals with a lower training volume can be predisposed to releasing higher amounts of troponins than more trained individuals. To our knowledge, regular training influences the cardiovascular system by increasing its capacity over the long term (27). The influence of body temperature on the relative change in troponin levels measured after the run is supported by the fact that hyperthermia can cause indirect muscle damage and relates to exhaustion and impairment of performance. Moreover, increased skin blood flow as prevention against hyperthermia is responsible for higher demands on the cardiovascular system and causes dehydration and reduced cardiac filling (28). Changes in creatinine concentrations can predict changes in the concentrations of troponins. We can hypothesize that the increase in these parameters (cardiac troponins and creatinine) could be used to monitor the appropriateness of the training burden. Although changes in creatinine can be explained by a higher metabolic rate during physical activity or by dehydration, there are no published data proving that a transient impairment in renal function, which is partly caused by dehydration, can cause substantial long-term renal damage.

We documented considerable changes in hsTnT and hsTnl levels in all participants after a 2-hour normalized treadmill run. In cases requiring medical attention for different indications, the use of a 0/1 algorithm is not applicable. If we simulated the clinical situation of a patient who has clinical signs of acute myocardial infarction after strenuous exercise, the $\mathrm{Oh} / \mathrm{h}$ algorithm did not exclude any participants. Approximately one quarter of healthy runners were assigned to the positive group and the majority remained in the "observe " group. However, none of the relatively well-trained runners had symptoms of myocardial infarction during the study. Additionally, we can presume that release of cTn in an untrained population after physical exercise is relatively frequent and can be caused by relatively low-intensity exercise, e.g. walking. Nevertheless, we agree with Shave et al. that in cases when medical attention is needed after physical exercise and the patient's history and clinical signs suggest a high probability of myocardial damage, troponin levels should be tested (5); however, they should be interpreted with caution.

Despite the tendency for troponin levels to return to baseline in the first 24 hours after the run in most cases, concentrations of hsTnT in one case and hsTnl in two different cases increased from 1 to 24 hours after the run. Middleton et al. (21) reported that a second concentration peak of troponin can be 
present, even 24 hours after the run. However, in a study by Tian et al. (6) in adults and adolescents, additional elevation of hsTnT after normalized exercise was not described. The presence of elevated troponin levels in the circulatory system after physical exercise can result from necrosis of a small number of cardiomyocytes; however, this theory has not been proven. Other authors have suggested that the initial peak of cTn can be caused by the release of a cytosolic pool of cTn, and a second peak can be caused by the release of cTn after proteolytic degradation (5). Although troponin modifications have been described in patients with myocardial infarction (29), the degradation of troponin molecules is not always associated with ischemia, as described in animal models (30). The cooccurrence of intact molecules and degradation products of troponin I was described in another study in patients with myocardial infarction (31). To the best of our knowledge, the presence of degradation products or intact molecules after physical exercise has not yet been studied in healthy individuals.

This study has strengths and limitations. Studies assessing changes in both high-sensitivity troponins during and after normalized exercise under laboratory conditions are rare. Our study focused on the consequences of using a $\mathrm{Oh} / \mathrm{h}$ algorithm to diagnose myocardial infarction and the description of a possible correlation with echocardiographic parameters and other parameters measured during the treadmill run. Additionally, renal parameters during standardized exercise were examined. Our study cohort included only healthy runners, most of whom had high or very high cardiorespiratory capacity. However, our conclusions cannot be generalized to the female population. Another limitation is the absence of echocardiographic examination after the run and the absence of haemoglobin assessment to reveal the influence of dehydration. In practice, however, the influence of

\section{References}

1. Thygesen K, Alpert JS, Jaffe AS, Simoons ML, Chaitman $B R$, White HD. Third universal definition of myocardial infarction. Circulation 2012; 126: 2020-35.

2. Jarolim P. High sensitivity cardiac troponin assays in the clinical laboratories. Clin Chem Lab Med (CCLM) 2015; 53(5): 635-52.

3. Lavie CJ, Lee D, Sui X, Arena R, O'Keefe JH, Church TS, Milani RV, Blair SN. Effects of running on chronic diseases and cardiovascular and all-cause mortality. Mayo Clin Proc 2015; 90: 1541-52.

4. Anđelković M, Baralić I, Đorđević B, Kotur Stevuljević J, Radivojević N, Dikić N, Radojević Škodrić S, Stojković M. Hematological and biochemical parameters in elite soccer players during a competitive half season. J Med Biochem 2015; 34: 460-6. hydration is not usually considered in the evaluation of hsTn levels and other laboratory parameters. Finally, the small sample size could also influence the robustness of our conclusion; and yet, this study was methodologically too complicated to include a larger number of participants.

\section{Conclusion}

Relative LV wall thickness, creatinine changes, training volume and body temperature after the run can predict changes in hsTnT and hsTnl levels. Increased levels of hsTn can be present even in cases when high-intensity or long-duration exercise is not undertaken. When medical attention is needed after physical exercise, hsTn levels should be tested only when clinical suspicion and the patient's history indicate a high probability of myocardial damage.

\section{Author contributions}

All the authors have accepted responsibility for the entire content of this submitted manuscript and approved the submission.

\section{Financial support}

The study was supported by the Ministry of Health, Czech Republic - Conceptual Development of Research Organisation (FNPI - 00669806).

\section{Conflict of interest statement}

The authors stated that they have no conflicts of interest regarding the publication of this article.

5. Lippi G, Banfi G. Exercise-related increase of cardiac troponin release in sports: An apparent paradox finally elucidated? Clinica Chimica Acta 2010; 411: 610-1.

6. Tian Y, Nie J, Huang C, George KP. The kinetics of highly sensitive cardiac troponin $\mathrm{T}$ release after prolonged treadmill exercise in adolescent and adult athletes. J Appl Physiol 2012; 113: 418-25.

7. Dželajlija DD, Spasić SS. Cardiovascular risk factors in 713 years old children from Vojvodina (Serbia). J Med Biochem 2016; 35: 293-301.

8. Roffi M, Patrono C, Collet J-P, Mueller C, Valgimigli M, Andreotti F, Bax JJ, Borger MA, Brotons C, Chew DP, Gencer B, Hasenfuss G, Kjeldsen K, Lancellotti P, Landmesser U, Mehilli J, Mukherjee D, Storey RF, Windecker S, Baumgartner H, Gaemperli O, Achenbach S, Agewall S, Badimon L, Baigent C, Bueno H, Bugiardini 
R, Carerj S, Casselman F, Cuisset T, et al. 2015 ESC Guidelines for the management of acute coronary syndromes in patients presenting without persistent ST-segment elevation: Task Force for the Management of Acute Coronary Syndromes in Patients Presenting without Persistent ST-Segment Elevation of the European Society of Cardiology (ESC). Eur Heart J 2016; 37: 267-315.

9. Casale PNMD, Devereux RBMD, Alonso DRMD, Campo E, Kligfield PMD. Improved sex-specific criteria of left ventricular hypertrophy for clinical and computer interpretation of electrocardiograms: validation with autopsy findings. Circulation 1987; 75: 565-72.

10. Lang RM, Badano LP, Mor-Avi V, Afilalo J, Armstrong A, Ernande L, Flachskampf FA, Foster E, Goldstein SA, Kuznetsova T, Lancellotti P, Muraru D, Picard MH, Rietzschel ER, Rudski L, Spencer KT, Tsang W, Voigt J-U. Recommendations for cardiac chamber quantification by echocardiography in adults: an update from the American Society of Echocardiography and the European Association of Cardiovascular Imaging. J Am Soc Echocardiogr 2015; 28: 1-39.e14.

11. Borg GAV. Psychophysical bases of perceived exertion. Med Sci Sports Exerc 1982; 14: 377-81.

12. Giménez MR, Twerenbold R, Boeddinghaus J, Nestelberger T, Puelacher C, Hillinger P, Wildi K, Jaeger C, Grimm K, Heitzelmann K-F, Sabti Z, Badertscher P, Cupa J, Honegger U, Schaerli N, Kozhuharov N, Lavallaz J du F de, Lopez B, Salgado E, Miró Ò, Martín-Sánchez FJ, Adrada ER, Morawiec B, Parenica J, Ganovska E, Neugebauer C, Rentsch K, Lohrmann J, Osswald S, Reichlin T, et al. Clinical effect of sex-specific cutoff values of highsensitivity cardiac troponin $\mathrm{T}$ in suspected myocardial infarction. JAMA Cardiol 2016; 1: 912-20.

13. Krintus $M$, Kozinski $M$, Boudry $P$, Capell NE, Köller $U$, Lackner K, Lefèvre G, Lennartz L, Lotz J, Herranz AM, Nybo $M$, Plebani $M$, Sandberg MB, Schratzberger W, Shih J, Skadberg $\varnothing$, Chargui AT, Zaninotto M, Sypniewska G. European multicenter analytical evaluation of the Abbott ARCHITECT STAT high sensitive troponin I immunoassay. Clin Chem Lab Med 2014; 52: 1657-65.

14. Chatard J-C, Mujika I, Goiriena JJ, Carré F. Screening young athletes for prevention of sudden cardiac death: Practical recommendations for sports physicians. Scand J Med Sci Sports 2016; 26: 362-74.

15. The New International Recommendations for Chronic Kidney Disease - AACC.org. https: //www.aacc.org/publications/cln/articles/2014/october/kidney-disease (8 March 2017)

16. Shave R, Baggish A, George K, Wood M, Scharhag J, Whyte G, Gaze D, Thompson PD. Exercise-Induced Cardiac Troponin Elevation: Evidence, Mechanisms, and Implications. Journal of the American College of Cardiology 2010; 56: 169-76.

17. Vilela EM, Bastos JCC, Rodrigues RP, Nunes JPL. Highsensitivity troponin after running-a systematic review. Neth J Med 2014; 72: 5-9.

18. Lippi G, Plebani M. High-sensitive troponin testing and the 'runner's syndrome'. J Emerg Med 2011; 41: 85-7.
19. Michieisen ECHJ, Wodzig WKWH, Van Dieijen-Visser MP. Cardiac troponin $\mathrm{T}$ release after prolonged strenuous exercise. Sports Medicine 2008; 38: 425-35.

20. Scherr J, Braun S, Schuster T, Hartmann C, Moehlenkamp S, Wolfarth B, Pressler A, Halle M. 72-h kinetics of high-sensitive troponin $T$ and inflammatory markers after marathon. Med Sci Sports Exerc 2011; 43: 1819-27.

21. Middleton N, George K, Whyte G, Gaze D, Collinson P, Shave R. Cardiac troponin $T$ release is stimulated by endurance exercise in healthy humans. J Am Coll Cardiol 2008; 52: 1813-4.

22. Shave R, George KP, Atkinson G, Hart E, Middleton N, Whyte G, Gaze D, Collinson PO. Exercise-induced cardiac troponin T release: a meta-analysis. Med Sci Sports Exerc 2007; 39: 2099-106.

23. Shave R, Ross P, Low D, George K, Gaze D. Cardiac troponin I is released following high-intensity short-duration exercise in healthy humans. Int J Cardiol 2010; 145: 337-9.

24. Scharhag J, Urhausen A, Schneider G, Herrmann M, Schumacher K, Haschke M, Krieg A, Meyer T, Herrmann W, Kindermann W. Reproducibility and clinical significance of exercise-induced increases in cardiac troponins and $\mathrm{N}$-terminal pro brain natriuretic peptide in endurance athletes. Eur J Cardiovasc Prev Rehabil 2006; 13: 388-97.

25. Neilan TG, Januzzi JL, Lee-Lewandrowski E, Ton-Nu T-T, Yoerger DM, Jassal DS, Lewandrowski KB, Siegel AJ, Marshall JE, Douglas PS, Lawlor D, Picard MH, Wood MJ. Myocardial injury and ventricular dysfunction related to training levels among nonelite participants in the Boston marathon. Circulation 2006; 114: 2325-33.

26. George K, Shave R, Oxborough D, Cable T, Dawson E, Artis N, Gaze D, Hew-Butler T, Sharwood K, Noakes T. Left ventricular wall segment motion after ultra-endurance exercise in humans assessed by myocardial speckle tracking. Eur J Echocardiogr 2009; 10: 238-43.

27. Lavie CJ, Arena R, Swift DL, Johannsen NM, Sui X, Lee D, Earnest CP, Church TS, O'Keefe JH, Milani RV, Blair $\mathrm{SN}$. Exercise and the cardiovascular system: clinical science and cardiovascular outcomes. Circ Res 2015; 117: 207-19.

28. Kenefick RW, Sawka MN. Heat exhaustion and dehydration as causes of marathon collapse. Sports Medicine 2007; 37: 378-81.

29. Labugger R, Organ L, Collier C, Atar D, Eyk JEV. Extensive troponin $\mathrm{I}$ and $\mathrm{T}$ modification detected in serum from patients with acute myocardial infarction. Circulation 2000; 102: 1221-6.

30. Feng J, Schaus BJ, Fallavollita JA, Lee T-C, Canty JM. Preload induces troponin I degradation independently of myocardial ischemia. Circulation 2001; 103: 2035-7.

31. Madsen LH, Christensen G, Lund T, Serebruany VL, Granger CB, Hoen I, Grieg Z, Alexander JH, Jaffe AS, Eyk JEV, Atar D. Time course of degradation of cardiac troponin I in patients with acute ST-elevation myocardial infarction. Circ Res 2006; 99: 1141-7. 